\title{
Waist circumference: a better predictor for lung ventilation than body mass index
}

\author{
Amjad F. Ahmad, Rajaa A. Yonis, Hazim M. Al-Habib \\ Department of Physiology, College of Medicine, University of Mosul.
}

(Ann. Coll. Med. Mosul 2010; 36 (1 \& 2): 12-17).

Received: $16^{\text {th }}$ Feb 2010; Accepted: $7^{\text {th }}$ Jul 2010.

\begin{abstract}
Objective: To evaluate the relationship between waist circumference, as a measure of central fat distribution, and lung ventilation function in both sexes among different weight categories in comparison with body mass index (BMI).

Subjects and Methods: One hundred healthy adults from both sexes were volunteered in this observational-cross-sectional study (53 males aged 19-69 years and 47 females aged 19-51 years). Subjects were recruited from Mosul Medical College students, teaching as well as administration staff. After collecting personal and health information necessary for the study, all subjects underwent anthropometric measurements (height, weight, and waist circumference) before spirometry test using computerized spirometer. The study was conducted in the Department of Medical Physiology-Mosul Medical College.

Results: All spirometric data were within $80-120 \%$ of the normal predicted values, thus excluding the possibility of any asymptomatic airway disease. A consistent negative correlation between, both waist circumference and BMI, with FVC and FEV1 were clearly observed in both sexes. Unlike BMI, waist circumference revealed stronger and significant negative correlation with lung function especially in male subjects. The significant negative correlation between waist circumference and FVC and FEV1 was more evident in overweight and obese subjects.

Conclusion: Waist circumference, as a measure of body fat distribution, seems more reliable predictor of poor lung function, secondary to overweight and obesity, than BMI. This might be attributed to the fact that BMI relies only on body weight and height without consideration to the distribution of body fat, muscle and bone mass which might possess a more significant role.
\end{abstract}

Keywords: Waist circumference, body fat distribution, lung function tests.

هدف البحث: لتقييم العلاقة بين محيط الخصر ، كمقياس لتوزيع الدهون في الجسم، ووظائف الرئة في كلا الجنسين

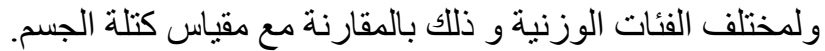

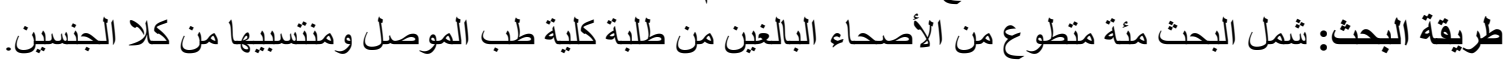

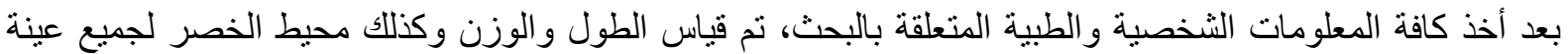
البحث وذللك قبيل إجر اء فحص وظائف الرئة باستخدام جهاز فحص وظائف التنفس الالكتروني (السبايروميتر) وقد تمت الدراسة في فرع الفسلجة الطبية في كلية طب المبل الموصل. نتائج البحث: أظهرت نتائج البحث ان جميع أفراد العينة كانوا ضمن المديات الطبيعية المتوقعة لقياسات وظائف الرئة

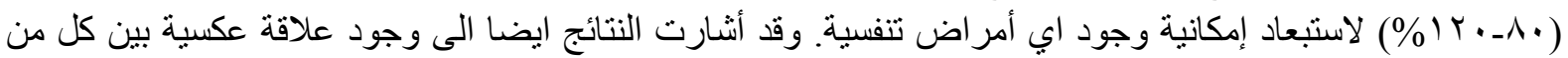
محيط الخصر ومقياس كتلة الجسم مع حجم الزفير القسري الكلي وحجم الزفير القسري في الثانية الاولى في كلا الجنسين. 


$$
\begin{aligned}
& \text { الا ان هذه العلاقة العكسية كانت أقوى وذات دلالة احصائية بالنسبة لمحيط الخصر خصوصا لاى الذكور وكذلك مجمو عة الألة }
\end{aligned}
$$

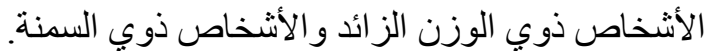

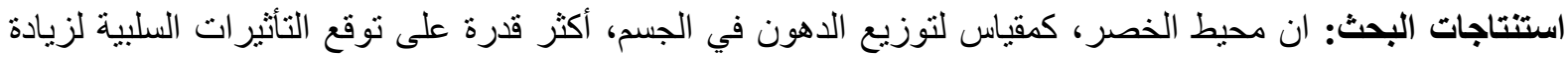

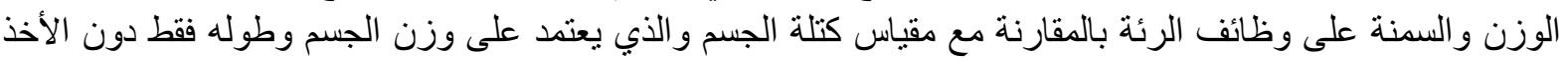

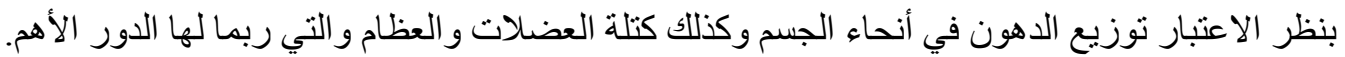

I is well known in medical practice that prediction of lung function is largely dependent on body anthropometry especially body height, weight, and body surface area. Body mass index (BMI), a measure of body weight in relation to height, is currently used to determine how thin or fat a person is. However, some argue that the error in the BMI is significant and it is not generally useful in evaluation of health ${ }^{(1,2)}$. Professor Eric Oliver from University of Chicago for political science says "BMI is a convenient but inaccurate measure of weight, and should be revised ${ }^{(3)}$. The National Institute of Health had recently reported some shortcomings of BMI. Because the BMI is dependent only upon weight and height, it makes simplistic assumptions about distribution of muscle and bone mass, and thus may overestimate adiposity on those with more lean body mass (e.g. athletes) while underestimating adiposity on those with less lean body mass (e.g. the elderly). A further limitation relates to loss of height through aging. In this situation, BMI will increase without any corresponding increase in weight $^{(4)}$.

Current studies on obesity revealed that health may be negatively affected when excess body fat has accumulated to a certain extent. Respiratory system involvement included obstructive sleep apnea, obesity hypoventilation syndrome and asthma. Several studies have reported a negative correlation between $\mathrm{BMI}$ and forced vital capacity (FVC) "a measure of the total volume of air that can be forcefully exhaled" and the forced expiratory volume in one second (FEV1), "a measure of the maximum volume of air expired in one second ${ }^{(5,6,7)}$. Although the influence of obesity on pulmonary function tests (PFTs) has been examined, there are limited studies to evaluate the association between body fat distribution and pulmonary function tests in overweight and moderate obesity $^{(8)}$. This study was attempted to evaluate the relationship between waist circumference "as a measure of central obesity in terms of body fat distribution" and pulmonary ventilation among different body weight groups in both sexes, in comparison with BMI.

\section{Subjects and methods}

One hundred healthy adults (53 males and 47 females) among Mosul Medical College students, teaching and administration staff volunteered in the present study. Details of age and anthropometric measurements are shown in table (1).

Table (1): The anthropometric characteristics of subjects according to gender. Values are expressed as range (mean $\pm \mathrm{SD})$.

\begin{tabular}{|l|c|c|c|}
\hline \multicolumn{1}{|c|}{ Parameter } & Total $(\mathrm{n}=100)$ & Male $(\mathrm{n}=53)$ & Female $(\mathrm{n}=47)$ \\
\hline Age $($ year $)$ & $19-69$ & $19-69$ & $19-51$ \\
& $33.75 \pm 12.74$ & $36.64 \pm 13.71$ & $30.48 \pm 10.79$ \\
\hline \multirow{2}{*}{ Height $(\mathrm{Cm})$} & $150-183$ & $150-183$ & $150-179$ \\
& $166.64 \pm 9.43$ & $172.01 \pm 8.17$ & $160.57 \pm 6.71$ \\
\hline \multirow{2}{*}{ Weight $(\mathrm{Kg})$} & $44-123$ & $47-123$ & $44-110$ \\
& $80.41 \pm 18.42$ & $88.23 \pm 16.97$ & $71.59 \pm 15.96$ \\
\hline \multirow{2}{*}{ Body mass index } & $18.5-40$ & $19-40$ & $18.5-40$ \\
& $29.33 \pm 5.98$ & $30.41 \pm 5.88$ & $28.11 \pm 5.93$ \\
\hline \multirow{2}{*}{ Waist circumference $(\mathrm{cm})$} & $58-133$ & $64-133$ & $58-126$ \\
& $95.67 \pm 18.13$ & $102.45 \pm 15.98$ & $88.02 \pm 17.48$ \\
\hline
\end{tabular}


Subject data sheet included all personal and health information necessary for the study. Our study group fulfilled the following criteria:

1. No history of any significant pulmonary or cardiac diseases. Never smoker.

2. Clear chest on physical examination.

3. Absence of any neuromuscular or musculoskeletal disorders which could affect spirometry test.

Anthropometric measurements: Height, weight and waist circumference were measured by using standard techniques as follows: height to within $0.5 \mathrm{~cm}$, without shoes; weight to within $100 \mathrm{~g}$, without heavy clothing; and waist circumference to within $0.1 \mathrm{~cm}$ by using plastic measuring tape, with the waist defined as midway between the lowest rib and the iliac crest as the participant breathed out gently ${ }^{(9)}$.

Spirometry: Forced vital capacity (FVC) and forced expiratory volume in 1 second (FEV1) were measured by using electronic spirometer (Discovery-2 version 8B Futurmed-America Inc.-Granada Hills, USA). Standard procedure were adopted following the recommendations of the American Thoracic Society (ATS) ${ }^{(10)}$. The forced expiratory vital capacity procedure was described and demonstrated to the subject before the test, emphasizing the tight fit between lips and tongue and encouraging the subject to breathe out as long and forcefully as possible. The best of three technically satisfactory maneuvers was recorded. The SPSS statistical package (windows version 8.0) was used to analyze the data.

\section{Results}

Table (1) shows the anthropometric data of subjects distributed according to gender. The study groups included normal weight, overweight as well as obese subjects for both sexes.

The percent predicted values for lung function parameters in both sexes are given in table (2). As expected, all spirometric parameters were well within the normal predicted range $(80-120 \%)$ insuring the absence of any asymptomatic airway disease: thus subjects perfectly fulfilled the criteria for inclusion in the study.

Table (3) revealed a consistent negative correlation between both waist circumference and BMI with FVC and FEV1in both sexes. Unlike BMI, waist circumference revealed stronger and significant negative correlation with lung function especially in male subjects.

Table (4): waist circumference and BMI continued to show negative correlation with lung function parameters FVC and FEV1 after redistributing the study group through different weight categories (normal weight, overweight and obese). The relationship was weaker and not significant in the normal weight group compared to that of overweight and obese groups. On the other hand, the relation between spirometric parameters and BMI was weak and not significant among all body weight categories.

Table (2): Spirometric parameters according to gender. Percent predicted values are given expressed as range (mean $\pm S D)$.

\begin{tabular}{|l|c|c|c|}
\hline Parameter & Total $(\mathrm{n}=100)$ & Male $(\mathrm{n}=53)$ & Female $(\mathrm{n}=47)$ \\
\hline \multirow{2}{*}{ FVC } & $82-116$ & $88-116$ & $82-110$ \\
& $(96.97 \pm 15.55)$ & $(93.66 \pm 13.59)$ & $(88.7 \pm 13.88)$ \\
\hline \multirow{2}{*}{ FEV1 } & $87-120$ & $90-120$ & $87-110$ \\
& $(93.19 \pm 15.77)$ & $(94.49 \pm 16.87)$ & $(91.72 \pm 14.46)$ \\
\hline FEV1\% & $83-115$ & $88-115$ & $83-99$ \\
& $(98.33 \pm 12.31)$ & $(101.35 \pm 8.23)$ & $(94.91 \pm 15.07)$ \\
\hline PEF & $80-110$ & $86-110$ & $80-95$ \\
& $(95.96 \pm 9.08)$ & $(97.38 \pm 9.57)$ & $(94.36 \pm 8.29)$ \\
\hline FMF & $88-111$ & $90-111$ & $88-102$ \\
& $(99.63 \pm 9.2)$ & $(101.6 \pm 9.7)$ & $(97.41 \pm 8.12)$ \\
\hline
\end{tabular}

FVC=Forced Vital Capacity, FEV1=Forced Expiratory volume in the first second, FEV1\%= Percent Forced Expiratory volume in the first second, $\mathrm{PEF}=$ Peak Expiratory Flow rate, FMF=Forced Midexpiratory Flow. 
Table (3): Correlation between waist circumference and BMI regarding their relationship with FVC and FEV1 according to gender.

\begin{tabular}{|c|c|c|c|c|c|}
\hline & \multicolumn{2}{|c|}{ FVC } & \multicolumn{2}{|c|}{ FEV1 } \\
\hline & & $r$ & $p$ & $\mathrm{R}$ & $P$ \\
\hline \multirow{3}{*}{$\begin{array}{l}\text { Waist } \\
\text { circumference }\end{array}$} & $\begin{array}{l}\text { Total } \\
(n=100)\end{array}$ & -0.44 & $* *$ & -0.32 & $\star *$ \\
\hline & $\begin{array}{l}\text { Male } \\
(n=53)\end{array}$ & -0.50 & ** & -0.46 & $\star *$ \\
\hline & $\begin{array}{l}\text { Female } \\
(\mathrm{n}=47)\end{array}$ & -0.33 & * & -0.32 & * \\
\hline \multirow{3}{*}{$\begin{array}{l}\text { Body mass } \\
\text { index }\end{array}$} & $\begin{array}{l}\text { Total } \\
(n=100)\end{array}$ & -0.15 & NS & -0.14 & NS \\
\hline & $\begin{array}{l}\text { Male } \\
(n=53)\end{array}$ & -0.12 & NS & -0.16 & NS \\
\hline & $\begin{array}{l}\text { Female } \\
(n=47)\end{array}$ & -0.09 & NS & -0.13 & NS \\
\hline
\end{tabular}

FVC=Forced Vital Capacity, FEV1=Forced Expiratory volume in the first second.

** correlation is significant at the 0.01 level (2tailed).

${ }^{*}$ correlation is significant at the 0.05 level (2-tailed).

Table (4): Correlation between waist circumference and BMI regarding their relationship with FVC and FEV1 according to body weight.

\begin{tabular}{|c|c|c|c|c|c|}
\hline & & \multicolumn{2}{|c|}{ FVC } & \multicolumn{2}{|c|}{ FEV1 } \\
\hline & & $r$ & $p$ & $r$ & $P$ \\
\hline \multirow{3}{*}{$\begin{array}{l}\text { Waist } \\
\text { circumference }\end{array}$} & $\begin{array}{l}\text { Normal } \\
\text { weight } \\
(n=28)\end{array}$ & -.15 & NS & -.13 & NS \\
\hline & $\begin{array}{l}\text { Overweight } \\
(n=31)\end{array}$ & -.45 & * & -.42 & * \\
\hline & $\begin{array}{l}\text { Obese } \\
(n=41)\end{array}$ & -.39 & * & -.31 & * \\
\hline \multirow{3}{*}{$\begin{array}{l}\text { Body mass } \\
\text { index }\end{array}$} & $\begin{array}{l}\text { Normal } \\
\text { weight } \\
(n=28)\end{array}$ & -.17 & NS & -.04 & NS \\
\hline & $\begin{array}{l}\text { Overweight } \\
(n=31)\end{array}$ & -.15 & NS & -.06 & NS \\
\hline & $\begin{array}{l}\text { Obese } \\
(n=41)\end{array}$ & -.23 & NS & -.07 & NS \\
\hline
\end{tabular}

FVC=Forced Vital Capacity, FEV1=Forced Expiratory volume in the first second

${ }^{*}$ correlation is significant at the 0.05 level (2-tailed).

\section{Discussion}

Waist circumference and (BMI) are indirect ways to assess body composition. Body mass index (BMI) has long been used as a simple means of assessing whether someone's weight put their health at risk. But increasingly, the value of this familiar measure is being called into question because it has been found that measurement of body fat and its distribution may be more important ${ }^{(6,9)}$. Waist circumference measurement has been increasingly related to ill health ${ }^{(9)}$. It reflects total and abdominal fat accumulation and is not greatly influenced by height ${ }^{(11)}$. However, other studies have shown that abdominal adiposity is an important indicator of reduced lung function in men; however, among women, the relationship is less clear $(12,13)$. In accordance with previous studies, our results in table (3) show a consistent negative correlation between $\mathrm{BMI}$ and waist circumference with both FVC and FEV1 in both sexes ${ }^{(12,14)}$. The reason for this significant negative association is not entirely clear, but it seems likely that a large waist circumference could have mechanical effects on lung function, that is, at least partially affecting movement of the diaphragm and chest wall. However, a large waist circumference is associated with fat, a metabolically active tissue, and other biologic effects cannot be ruled out ${ }^{(5)}$. Apart from other spirometric parameters measured in the present study, only FVC and FEV1 was considered owing to their stronger predictive power for restrictive impairment of lung function currently observed in obesity $(15,16)$. Referring back to table (3), waist circumference revealed stronger and significant relation with FVC and FEV1 in both sexes especially males ( $r=-0.50$ for FVC and -0.46 for FEV1 for waist circumference compared to -0.12 for FVC and -0.16 for FEV1 for BMI). This is in accordance with Raidal et al study ${ }^{(7)}$ which reported that body fat distribution has independent effect on lung function that were more prominent in men than women. In an Australian study of the effects of body composition and fat distribution on ventilatory function, Lazarus et al. ${ }^{(17)}$ investigated a single measurement, FVC only, and observed that it was significantly negatively correlated with waist circumference in men but not in women. On the other hand, 
the predominance of waist circumference over BMI might be partially explained by the study of Han et al in $1997^{(11)}$ who concluded that height and age had limited influences on the differences in waist among Caucasian subjects of different stature and waist alone may be used to indicate adiposity or to reflect metabolic risk factors. In contrast, the influence of height on body weight, and consequently on BMI, was important. The present study also enquired whether the negative relation of $\mathrm{BMI}$ and waist circumference with lung function is maintained through different body weight categories For that reason, subjects were regrouped into different weight categories according to the international classification of obesity for Asian populations ${ }^{(18)}$ as follows:

1. Normal weight group: $\mathrm{BMI}=18.5-25$.

2. Overweight group: $\mathrm{BMI}=25-30$.

3. Obese group (class I, class II): BMI=30-40. Subjects with $\mathrm{BMI} \geq 40$ (class III obesity) were excluded from the study because measurement of waist circumference in this category adds little to the predictive power of $\mathrm{BMI}$ as most individuals with this BMI have an abnormal waist circumference ${ }^{(8)}$. In addition to difficulty collecting such obese subjects.

Data given in table (4) reveal that the negative relation of $\mathrm{BMI}$ and waist circumference with lung function continued through different body weight categories. However, the relationship was stronger and significant with waist circumference, rather than BMI, in the overweight and obese groups. This finding agrees with previous studied on different lung function parameters in relation to body fat distribution on men and women separately which concluded that lung volumes (Forced vital capacity FVC, Total lung capacity TLC, Functional residual capacity FRC, and Expiratory reserve volume ERV) were all substantially affected in overweight and obese subjects. Apart from impact of obesity on lung volumes, other studies mentioned an effect of obesity on lung diffusion as well. Prefault et al (19) showed a reduced DLCO and carbon monoxide transfer coefficient in $20 \%$ of obese persons, and it was related to the disorder in ventilation distribution and significant decrease in closing volume at the end of expiration; however, Rubinstein et al ${ }^{(20)}$ found an increase in $\mathrm{CO}$ diffusion.

\section{Conclusion}

Lung ventilation function is affected in overweight and obese persons in relation to body fat distribution especially in men. Therefore, pulmonary function tests, especially lung volumes, must be interpreted carefully in this population. Accordingly, it seems reasonable to consider the waist circumference measurement before interpreting the spirometry report of obese subjects.

\section{References}

1. "Do You Believe in Fairies, Unicorns, or the BMI?". Mathematical Association of America. 2009-05-01. http://www.maa.org/ devlin/devlin.

2. "Is obesity such a big, fat threat?" 200408-30. http://www.rockymounttelegram. com / featr / content/shared / health/stories /BMI.

3. "Oliver blames 'obesity mafia' for American weight scare" (April 26, 2005). http:// thedartmouth.com/2005/04/26/news/oliver.

4. "Aim for a Healthy Weight: Assess your Risk". National Institutes of Health. 200707-08. http:// www.nhlbi.nih.gov/health/ public/heart/obesity/lose_wt/risk.htm\#limita tions.

5. Ruoling C, Hugh T, Caroline B-, Mary K. H and Caroline M. Association of Dietary Antioxidants and Waist Circumference with Pulmonary Function and Airway Obstruction. American Journal of Epidemiology 2001;153; 2 : 157-163.

6. Lazarus R, Sparrow D, Weiss ST. Effects of obesity and fat distribution on ventilatory function: the normative aging study. Chest 1997;111:891-898.

7. Raidal I, Harik-Khan RI, Wise RA, Fleg JL. The effect of gender on the relationship between body fat distribution and lung function. J Clin Epidemiol 2001;54:399406.

8. Chen $Y$, Rennie $D$, Cormier $Y F$, et al. Waist circumference is associated with pulmonary function in normal-weight, 
overweight, and obese subjects. Am J Clin Nutr 2007; 85:35-39.

9. Lean MEJ, Han TS, Seidell JC. Impairment of health and quality of life in people with large waist circumference. Lancet 1998; 351:853-856.

10. Official Statement of the American Thoracic Society: single-breath carbon monoxide diffusing capacity (transfer factor); recommendations for standard technique-1995 update. Am. J. Respir. Crit. Care. Med. 1995; 152: 2185-2198.

11. Han TS, Seidell JC, Curral JEP, et al. The influence of height and age on waist circumference as an index of adiposity in adults. Int J Obes 1997;21:83-98.

12. Bray GA. Complications of obesity. Ann Intern Med 1985;103:1052-1062.

13. Canoy D, Luben R, Welch A, et al. Abdominal obesity and respiratory function in men and women in the EPIC-Norfolk Study, United Kingdom. Am J Epidemiol 2004;159:1140-1149.

14. Sue DY. Obesity and pulmonary function: more or less? Chest 1997;111:844-845.
15. Collins LC, Hoberty PD, Walker JF, et al. The effect of body fat distribution on pulmonary function tests. Chest 1995;107:1298-1302.

16. Jenkins SC, Moxham J. The effects of mild obesity on lung function. Respir Med 1991;85:309-311.

17. Lazarus R, Gore CJ, Booth $M$, et al. Effects of body composition and fat distribution on ventilatory function in adults. Am J Clin Nutr 1998; 68:35-41.

18. WHO expert consultation. Appropriate body-mass index for Asian populations and its implications for policy and intervention strategies. The Lancet 2004; 157-163.

19. Prefaut $\mathrm{C}$, Ramonatxo M, Monnier L, et al. Mechanical effects of obesity on lung function. Pathol Biol 1980;28:149-154.

20. Rubinstein I, Zamel N, DuBarry L, et al. Airflow limitation in morbidly obese, nonsmoking men. Ann Intern Med 1990;112:828-832. 